九州大学学術情報リポジトリ

Kyushu University Institutional Repository

\title{
Performance Study of Adsorption Cooling Cycle for Automotive Air-conditioning
}

Ali, Syed Muztuza

School of Mechanical Aerospace Engineering, Nanyang Technological University

Chakraborty, Anutosh

School of Mechanical Aerospace Engineering, Nanyang Technological University

https://doi.org/10.5109/1500423

出版情報: Evergreen. 2 (1)，pp. 12-22，2015-03. Green Asia Education Center バージョン：

権利関係 : 


\title{
Performance Study of Adsorption Cooling Cycle for Automotive Air-conditioning
}

\author{
Syed Muztuza Ali ${ }^{1}$, Anutosh Chakraborty ${ }^{2, *}$ \\ ${ }^{1}$ School of Mechanical and Aerospace Engineering, Nanyang Technological University, \\ 50 Nanyang Avenue Singapore, 639798 \\ ${ }^{2}$ School of Mechanical and Aerospace Engineering, Nanyang Technological University, \\ 50 Nanyang Avenue Singapore, 639798
}

*Author to whom correspondence should be addressed, E-mail: AChakraborty@ntu.edu.sg

(Received January 20, 2015; accepted March 2, 2015)

\begin{abstract}
Exhaust gas from automobile can be used to drive adsorption cooling based air conditioning system for the vehicle cabin. This study describes the thermodynamic framework of a two stage indirect exhaust heat recovery system of automotive engine and an effective lumped parameter model to simulate the dynamic behaviors of an adsorption chiller that ranges from the transient to the cyclic steady states. Silica gel and water are used as adsorbent - adsorbate pair. The adsorption chiller model is developed from the rigor of mass and energy balances of each components of the system employing the experimentally confirmed isotherms and kinetics data of silica gel-water system. The performances of the chiller are calculated in terms of COP (Coefficient of Performance) and SCP (Specific Cooling Power) for different operating parameters such as cycle time, switching time, exhaust gas temperatures and flow rates. From the simulation, it is found that the exhaust energy of a six cylinder $3000 \mathrm{cc}$ private car is able to produce enough cooling power for the car cabin. It is also observed that the driving heat source temperature of the adsorption cooling system does not remain constant throughout the cycle time rather it varies in the range depending on the design of the heat recovery system. The optimized COP and SCP of cooling system are found to be 0.47 and 0.25 $\mathrm{kW} / \mathrm{kg}$, respectively.
\end{abstract}

Keywords: Adsorption Chiller, COP, Silica gel - water, SCP

\section{Introduction}

Due to the population boom in the last four decades of twentieth century, the private transport requirement is being raised very fast. The number of cars registered worldwide in 1960 was 98,305 whereas this number increased seven times and reached to 707,764 in $2010^{1)}$. The conventional automotive air conditioners (AC) of these cars use the engine shaft power to run the mechanical compressor. It imposes an extra $10 \%$ load on engine, which in turn increases the fuel consumption and exhaust gas production ${ }^{2)}$. The growing number of cars and their AC-systems are consuming more fuel which contributes to serious energy crisis. It causes ecological problems also by emitting $\mathrm{CO}_{2}, \mathrm{SO}_{\mathrm{X}}, \mathrm{NO}_{\mathrm{X}}$, lead etc. with the exhaust gas of engine ${ }^{3-5)}$. The specific fuel consumption of the vehicle can be minimized by utilizing the exhaust gases as motive energy source of cooling system. Thermally driven cooling devices such as ab/adsorption cooling system employ waste heat to produce chilled water. It can open a new avenue for the sustainable development of environmentally friendly airconditioning system. It should be noted that $35 \%$ of total energy supplied to a petrol engine based private car remains unused and wasted as exhaust gas $^{6-7)}$. Employing the unused exhaust heat, adsorption cooling system for automotive car can be developed where the refrigerant (water vapor) pressure is raised from the evaporator pressure to the condenser pressure during the desorption processes. Heat is thus pumped from low temperature region (car cabin) to the environment. Regardless of having energy saving and environmentally friendly features, the adsorption cooling system is not being used as automotive air-conditioner due to its low coefficient of performance, low specific cooling power and complex exhaust energy recovery system. Previous research activities reported that the Coefficient of Performance (COP) and the Specific Cooling Power (SCP) of adsorption cooling cycle (ADC) using silica gel+water are 0.4 and $0.3 \mathrm{~kW} / \mathrm{kg}$, respectively ${ }^{8-28)}$.

Numerous researches were carried out to study the 
performance of $\mathrm{ADC}$ for automotive $\mathrm{AC}$ in terms of $\mathrm{COP}$ and SCP. Wang, R.Z. et al. designed an adsorption airconditioner for the driver's cabin of a diesel locomotive system with zeolite-water as working pair ${ }^{29}$. The influences of operating conditions on the system performances were analyzed by simulation and experiments. In this paper, the temperature of each component ranging from transient to steady state was simulated with respect to cooling capacity and COP. The effects of sorption beds, evaporation and condensation temperatures on cooling capacity and COP were experimentally measured for various cycle and switching times. Metrans transportation centre investigated the feasibility of required cooling needs for commercial tractor-trailer refrigeration and transit bus air conditioning employing exhaust heat with adsorption refrigeration systems ${ }^{2)}$. An experimental vapor compression air conditioning system utilizing adsorption compression was refurbished and operated to verify previously reported coefficient of performance (COP) and specific cooling power (SCP) values. Lambert, M. A. and Jones, B. J. carried out a conceptual and embodiment design of an exhaust-powered adsorption air conditioner ${ }^{30}$. The design was preceded by the detailed discussion of automotive cooling requirements and compared with other thermally powered cooling technologies. They presented the detailed design and analysis of an automotive adsorption AC, particularly the critical components, adsorption bed and desorption bed in another study ${ }^{31}$. Zhong, Y.F. et al. proposed an adsorption air conditioning system to provide cooling for heavy-duty vehicles ${ }^{32}$. This system was powered by waste heat when the engine is running. A model of the adsorption system using zeolite-water working pair was developed and the system performances with different operating cycles were reported ${ }^{32}$. The dynamic performance of the system provided guidance for the system control and energy minimization. Verde M. et al. developed a dynamic model of water-zeolite based adsorption-desorption system for the cooling of vehicle cabin employing the waste heat at the engine hydraulic loop and calculated the sequential operation of (a) adsorption-desorption cycle, (b) the condensed water per cycle and (c) the cooling effects produced at the evaporator ${ }^{33)}$.

The previous studies ${ }^{2,29-33)}$ presented the modelling and simulation to predict the performances of the adsorption cycles and they did not describe and investigate the behaviors of the exhaust gas heat recovery system, which drives the adsorption cooling system and influences its performances significantly. This paper aims to evaluate the exhaust gas heat recovery system with its complete dynamic model which is able to estimate the temporal behaviors of all the heat transfer fluids over time. This study also presents a lumped model of adsorption cooling system using silica gel, water as adsorbent adsorbate pair and combines it with the model of exhaust gas heat recovery system. Finally it looks into the effects of cycle time, switching time, exhaust gas temperature, cooling water temperature and mass flow rates of exhaust gas, hot water and cooling water on COP and SCP of adsorption cooling system.

\section{Description of adsorption cooling system}

The design of adsorption cooling system for automotive air conditioning comprises five main components: two sorption beds (adsorption bed and desorption bed), an evaporator, a condenser and a metering valve and these are shown in Fig. 1. The flow of refrigerant (here water) through these components is controlled by sequentially opening and closing of valves V1, V2, V3 and V4. The hot and the room temperature cold water circulation through the sorption beds are controlled by switching on and off the valves S1, S2, S3, S4, S5, S6, S7 and S8 alternatively as shown in Figure 1. The chilled water receives heat from the vehicle cabin and flows through the tube side of the evaporator. On the shell side of the evaporator, the refrigerant water receives the heat as latent heat of evaporation at very low pressure (about $1 \mathrm{kPa}$ ) and evaporates at the temperature of about $7^{\circ} \mathrm{C}$. The water vapor is then adsorbed onto the porous surface of the adsorbent material within the adsorption bed at evaporator pressure. In this study, silica gel-water pair is chosen as the adsorbent-adsorbate pair, as it is available and its minimum regeneration temperature is also low, which is about $65^{\circ} \mathrm{C}^{34-36}$. Since the adsorption is an exothermic process and the water adsorption capacity of silica gel reduces at higher temperature, cooling water must flow through the adsorption bed. During the desorption process, the hot water is circulated though the desorption bed and water vapor is desorbed. The regenerated water vapor goes to the condenser for condensation purposes, and finally the condensed water is refluxed back to the evaporator via the u-tube or the metering valve. The cooling water that passes through the adsorption bed and condenser is circulated through the air cooled radiator of the car to reduce its temperature to the atmospheric temperature. The metering valve maintains the pressure difference between the evaporator and the condenser. Two sorption beds are utilized to achieve continuous cooling by alternating the adsorption and desorption process in each bed. Each cycle consists of two operations, namely the normal operation and the switching operation. During the normal operation mode, the adsorption and desorption processes take place in the sorption beds. All the beds are isolated from the evaporator and condenser during the switching operation. The adsorption bed is preheated by hot water so that its pressure increases from evaporator pressure to condenser pressure. On the other hand, the cooling water is circulated through the desorption bed in order to reduce its pressure from condenser pressure to the evaporator pressure. The cooling effect is obtained only during the normal or adsorption/desorption operation. 


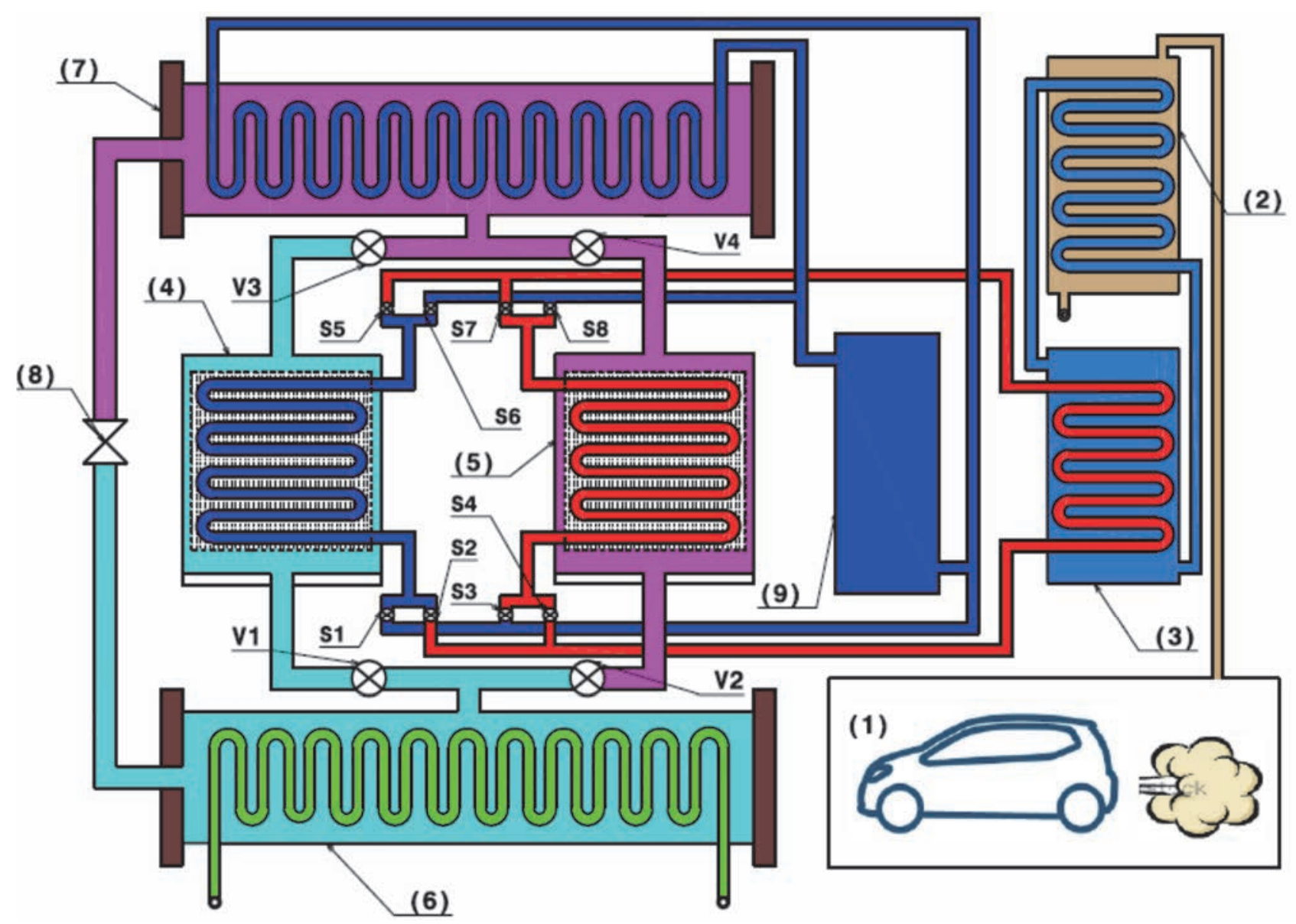

1. Exhaust Energy Source

2. Economizer

3. Generator

4. Adsorption Bed

5. Desorption Bed
6. Evaporator

7. Condenser

8. Metering Valve

9. Air cooled radiator

Refrigerant Control Valve: V1, V2, V3, V4:

Cooling Water/Hot Water Switching Valve : S1, S2, S3, S4

Fig. 1 Schematic Diagram of Exhaust Gas Driven Adsorption Cooling System.

\section{Exhaust energy recovery system}

Adsorption cooling system needs adsorption and desorption processes simultaneously to achieve continuous cooling. The desorption process requires heat energy inflow to regenerate the adsorbed water vapor. This driving heat energy can be obtained from automotive engine exhaust gas. Considering the COP of the system $0.4,7.5 \mathrm{~kW}$ exhaust energy is needed to deliver $3 \mathrm{~kW}$ cooling capacity which is the typical cooling load for a 4seater small automobile. The internal combustion engine of six cylinders $(3000 \mathrm{cc})$ possesses an average exhaust gas temperature of $353^{\circ} \mathrm{C}$ and it is released to the surrounding environment as waste heat ${ }^{30-31,37)}$. Part of this waste heat can be recovered and used as the heat energy source for the adsorption cooling system. In order to achieve this, a heat recovery system is designed and simulated. In this study, water is considered as adsorbate, therefore, the high temperature of exhaust gas renders it impractical to directly transfer heat from exhaust gas to the adsorption cooling system. To solve this problem, a two-stage heat recovery system comprises two parallelflow shell and tube heat exchangers are designed. The first heat exchanger serves as an economizer and the second one as a generator - which is directly connected to the adsorption cooling system as shown in Fig. 1. These two heat exchangers are then connected by heat transfer oil with in a closed-loop. The heat transfer oil (Shell Heat Transfer Oil S2) with Cp of $2.67 \mathrm{~kJ} / \mathrm{kg}-\mathrm{K}$ and flash point of $220^{\circ} \mathrm{C}$ is chosen to serve as working fluid ${ }^{38)}$.

The economizer is a gas-to-liquid heat exchanger where 
the exhaust gas flows through the shell side and oil through the tube side. The exhaust gas heats up the intermediate fluid oil. This heated oil then goes into the generator where it circulates through the shell side and water through the tube side. Heat is transferred from oil to water. Hot water from the generator is finally circulated through the desorption bed to provide the desorption energy to the ADC. The exhaust heat recovery system with a $3 \mathrm{~kW}$ adsorption cooling system with its can be installed behind the back seat of a car sacrificing some luggage space.

\section{Thermodynamic model}

\subsection{Adsorption isotherms and kinetics}

Adsorption isotherm model is used to determine the amount of adsorbate vapor uptake under equilibrium conditions at different temperatures and pressures. Several isotherm models have been developed for the simulation of ADC. In this study Toth's isotherm model ${ }^{39-41)}$ is employed and is given by equation (1).

$$
w^{*}=\frac{w_{m} K_{0} \exp \left(\frac{H_{a d s}}{R T}\right) P}{\left[1+\left\{K_{0} \exp \left(\frac{H_{a d s}}{R T} P\right)\right\}^{t}\right]^{1 / t}}
$$

where $\mathrm{w}^{*}$ is the amount of adsorbate at equilibrium conditions, $\mathrm{w}_{\mathrm{m}}$ denotes the monolayer uptake capacity, $\mathrm{H}_{\text {ads }}$ is the heat of adsorption, $\mathrm{K}_{0}$ is the pre-exponential constant and $t$ is the dimensionless Toth's constant. The experimentally measured isotherm data are fitted with equation (1). The fitted parameters are shown in Table 1.

Table 1 Isotherm properties of silica gel ${ }^{34-36)}$.

\begin{tabular}{|c|r|l|l|l|}
\hline Type & $\begin{array}{r}w_{m} \\
(\mathrm{~kg} / \mathrm{kg})\end{array}$ & $K_{0}\left(\mathrm{~Pa}^{-1}\right)$ & $\begin{array}{r}H_{a d s} \\
(\mathrm{~kJ} / \mathrm{kg})\end{array}$ & $\mathrm{t}$ \\
\hline Silica gel & 0.4 & $7.3 \times 10^{-13}$ & 2800 & 8 \\
\hline
\end{tabular}

The transient uptakes of water vapor on silica gel for various temperatures and pressures are given by adsorption kinetics, which is calculated by the linear driving force (LDF) model $^{39-41)}$ as shown in equation (2).

$$
\frac{d w}{d T}=\frac{15 D_{s o} \exp \left(\frac{-E_{a}}{R T}\right)}{R_{P}^{2}}\left(w^{*}-w\right)
$$

where $\mathrm{D}_{\text {so }}$ is the kinetic constant, $\mathrm{E}_{\mathrm{a}}$ is the activation energy, $\mathrm{R}_{\mathrm{p}}$ is the particle radius, $\mathrm{w}^{*}$ is the equilibrium uptake, and $\mathrm{w}$ denotes the instantaneous uptake. LDF equation parameters are listed in Table 2.
Table 2 LDF equation parameters of Silica gel $^{34-36)}$.

\begin{tabular}{|l|c|c|c|}
\hline Type & $\begin{array}{c}D_{S o} \\
\left(\mathrm{~m}^{2} / \mathrm{S}\right)\end{array}$ & $\begin{array}{c}E_{a} \\
(\mathrm{~kJ} / \mathrm{mol})\end{array}$ & $R_{P}(\mathrm{~m})$ \\
\hline Silica & & & \\
gel & $2.54 \times 10^{-4}$ & 42 & $0.17 \times 10^{-3}$ \\
\hline
\end{tabular}

\subsection{Energy balance}

In this manuscript, the lumped parameter model is used to describe the energy balance of all components of adsorption cycle, where the components of heat exchangers such as tube, fin metal, fluids and adsorbent materials are assumed to have the same temperature at the beginning of the cycle or $t=0$. The energy balance of the economizer is presented by

$$
\begin{aligned}
& M C_{p, H X} \frac{d T_{H X, E g}}{d t}=\dot{m} C_{p, E g}\left(T_{E g, \text { in }}-\right. \\
& \left.T_{E g, \text { out }}\right)-\dot{m} C_{p, \text { Oil }}\left(T_{\text {Oil }, \text { out }}-T_{\text {oil,in }}\right)
\end{aligned}
$$

where $M$ is the mass of the heat exchanger tube, $C_{p, H X}$ is the specific heat capacity of the heat exchanger tube material $\mathrm{dT}_{\mathrm{HX}, \mathrm{Eg}} / \mathrm{dt}$ is the rate of change of heat exchanger temperature, $\dot{m}$ is the mass flow rate of exhaust gas, $\mathrm{C}_{\mathrm{p}, \mathrm{Eg}}$ is the specific heat of exhaust gas, $T_{E g \text {,in }}$ and $T_{E g \text {,out }}$ are the inlet and outlet temperatures of exhaust gas, $\dot{m}_{\text {Oil }}$ is the mass flow rate of oil, $C_{p, O i l}$ is the specific heat of oil, and $T_{\text {oil,out }}$ and $T_{\text {Oil,in }}$ are the inlet and outlet temperatures of oil. Equation (3) shows that the rate of change of heat exchanger temperature is proportional to the amount of energy supplied by the exhaust gas and inversely proportional to the amount of energy delivered to the oil. The outlet temperature of the oil from economizer is estimated using log mean temperature difference method and is expressed by eqn. 4 .

$$
\begin{aligned}
& T_{\text {Oil,out }}=T_{H X, E g}+\left(T_{\text {Oil,in }}-\right. \\
& \left.T_{H X, E g}\right) \exp \left\{\frac{-U A}{\dot{m}_{\text {Oil }} C_{p, \text { Oil }}}\right\},
\end{aligned}
$$

where $\mathrm{U}$ is the overall heat transfer coefficient of heat exchanger determined by the Dittus-Boelter equation ${ }^{42)}$, A is the heat transfer surface area. The hot oil from the economizer is circulated through the generator and flows back to the economizer. So the outlet temperature of oil from economizer is considered as the inlet temperature of the generator. The energy balance of the generator is given by

$$
\begin{aligned}
& \left(M_{H X, \text { Oil }} C_{p, H X}+M_{\text {Oil }} C_{p, \text { Oil }}\right) \frac{d T_{H X, O i l}}{d t}= \\
& \dot{m}_{\text {Oil }} C_{p, \text { oil }}\left(T_{\text {Oil }, \text { in }}-T_{\text {Oil }, \text { out }}\right)- \\
& \dot{m}_{\text {water }} C_{p, \text { water }}\left(T_{\text {water,out }}-T_{\text {water,in }}\right)
\end{aligned}
$$


where $M_{\text {Oil }}$ is the amount of oil which is always stored in the generator, $\dot{m}_{\text {water }}$ is the mass flow rate of water, $C_{p, \text { water }}$ is the specific heat of water, $T_{\text {water,out }}$ and $T_{\text {water,in }}$ are the outlet and inlet temperatures of water. $T_{\text {Oil,out }}$, the outlet temperature of oil from generator is considered as the inlet temperature of the economizer. The outlet temperature of water is estimated by equation (6).

$$
\begin{aligned}
& T_{\text {water,out }}=T_{H X, \text { oil }}+\left(T_{\text {water, }, \text { }}-\right. \\
& \left.T_{H X, \text { oil }}\right) \exp \left\{\frac{-U A}{\dot{m}_{\text {water }} C_{p, \text { water }}}\right\}
\end{aligned}
$$

The hot water outlet from the generator is used to heat up the desorption bed. Hence the outlet temperature of water from the generator is used as the hot water inlet temperature of the sorption bed. The energy balance of the sorption bed is given by equation (7).

$$
\begin{aligned}
& \left(M_{a d s} C_{p, a d s}+M_{H X, b e d} C_{p, H X}+\right. \\
& \left.M_{a b e} C_{p, a b e}\right) \frac{d T_{a d s / d e s}}{d t}= \pm H_{a d s} M_{a d s} \frac{d w_{a d s / d e s}}{d t} \pm \\
& \dot{m}_{c w / h w} C_{p, c w / h w}\left(T_{a d s / d e s}\right)\left(T_{c w / h w, i n}-\right. \\
& \left.T_{c w / h w, o u t}\right),
\end{aligned}
$$

where the left hand side of the equation provides the amount of sensible heat required to cool down or heat up the adsorbent, adsorbate and heat exchanger tube. The first term on the right hand side represents the heat input during desorption process or the heat released during adsorption process. The second term indicates the total amounts of heat added to the system during desorption or heat released during adsorption process. The outlet temperatures of the water from both sorption beds are calculated by equations (8) and (9) respectively.

$$
\begin{aligned}
& T_{c w, \text { out }}=T_{\text {bed }}+\left(T_{c w, \text { in }}-\right. \\
& \left.T_{\text {bed }}\right) \exp \left\{\frac{-U A}{\dot{m}_{c w} C_{p, c w}\left(T_{b e d}\right)}\right\} \\
& T_{h w, \text { out }}=T_{\text {bed }}+\left(T_{h w, i n}-\right. \\
& \left.T_{\text {bed }}\right) \exp \left\{\frac{-U A}{\dot{m}_{h w} C_{p, h w}\left(T_{b e d}\right)}\right\}
\end{aligned}
$$

The energy balance of the condenser is expressed by ${ }^{13-14)}$

$$
\begin{aligned}
& \left(M_{\text {cond }}^{\text {ref }} C_{p}\left(T_{\text {cond }}\right)+M_{H X, \text { cond }} C_{p, H X}\right) \frac{d T_{\text {cond }}}{d t}= \\
& h_{f}\left(T_{\text {cond }}\right) M_{a d s} \frac{d w_{\text {des }}}{d t}- \\
& \dot{m}_{c w} C_{p, c w}\left(T_{\text {cond }}\right)\left(T_{\text {cond,out }}-T_{\text {cond }, \text { in }}\right)- \\
& h_{f g}\left(T_{\text {cond }}\right) M_{a d s} \frac{d w_{d e s}}{d t}
\end{aligned}
$$

The outlet temperature of water from condenser heat exchanger is given by

$$
\begin{aligned}
& T_{\text {cond,out }}=T_{\text {cond }}+\left(T_{\text {cond }, \text { in }}-\right. \\
& \left.T_{\text {cond }}\right) \exp \left\{\frac{-U A}{\dot{m} C_{p, h w}\left(T_{\text {cond }}\right)}\right\}
\end{aligned}
$$

The energy balance of the evaporator ${ }^{13-14)}$ is written as

$$
\begin{aligned}
& \left(M_{\text {evp }}^{r e f} C_{p}\left(T_{\text {evp }}\right)+M_{H X, \text { evp }} C_{p, H X}\right) \frac{d T_{\text {evp }}}{d t}= \\
& \dot{m}_{c h w} C_{p, c h w}\left(T_{\text {evp }}\right)\left(T_{c h w, i n}-T_{c h w, o u t}\right)- \\
& h_{f g}\left(T_{\text {evp }}\right) M_{a d s} \frac{d w_{a d s}}{d t}-h_{f}\left(T_{\text {cond }}\right) M_{a d s} \frac{d w_{\text {des }}}{d t}
\end{aligned}
$$

The outlet temperature of water from evaporator heat exchanger is given in equation (13)

$$
T_{\text {evp }, \text { out }}=T_{\text {evp }}+\left(T_{\text {evp in }}-T_{\text {evp }}\right) \exp \left\{\frac{-U A}{m C_{p, \text { chw }}\left(T_{\text {evp }}\right)}\right\} \quad \text { (13 }
$$

\subsection{Mass balance}

Neglecting the mass of gaseous phase of refrigerant, the mass balance of $\mathrm{AD}$ cooling system is written as,

$$
\frac{d M_{r e f}}{d t}=-M_{a d s}\left(\frac{d w_{a d s}}{d t}+\frac{d w_{d e s}}{d t}\right)
$$

where $M_{a d s}$ is the amount of adsorbent used per sorption bed, $w_{\text {ads }}$ and $w_{\text {des }}$ is the amount of water vapor adsorbed and desorbed during adsorption and desorption processes.

\subsection{System performances}

The energy required to regenerate the water vapor from the adsorbent is expressed by

$$
Q_{\text {des }}=\dot{m}_{h w} C_{p}\left(T_{\text {des }}\right)\left(T_{h w, \text { in }}-T_{h w, o u t}\right)
$$

Concurrently, the energy rejected to adsorb water vapor into the adsorbent material is calculated by

$$
Q_{a d s}=\dot{m}_{c w} C_{p}\left(T_{a d s}\right)\left(T_{c w, o u t}-T_{c w, i n}\right)
$$

The heat removed from the regenerated water vapor to change its phase to liquid is estimated by

$$
\begin{gathered}
Q_{\text {cond }}=\dot{m}_{c w} C_{p, c w}\left(T_{\text {cond }}\right)\left(T_{\text {cond }, \text { out }}\right. \\
\left.-T_{\text {cond }, \text { in }}\right)
\end{gathered}
$$

The energy received from the chilled water to evaporate the refrigerant water is given by

$$
\begin{gathered}
Q_{\text {evp }}=\dot{m}_{c h w} C_{p, c h w}\left(T_{\text {evp }}\right)\left(T_{\text {chw }, \text { in }}\right. \\
\left.-T_{\text {chw }, \text { out }}\right)
\end{gathered}
$$

The energy balance of the ADC can be written as

$$
Q_{\text {des }}+Q_{\text {evp }}=Q_{\text {des }}+Q_{\text {cond }}
$$

The cycle average heat supplied by the exhaust gas to the 
circulating intermediate heat transfer fluid (oil) is given by

$$
Q_{E g}=\frac{\int_{0}^{t_{c y c l e}} \dot{m}_{E g} C_{p, E g}\left(T_{E g, \text { in }}-T_{E g, \text { out }}\right) d t}{t_{\text {cycle }}}
$$

Here $t_{\text {cycle }}$ is the total duration of adsorption or desorption processes and switching process and is expressed by

$$
t_{\text {cycle }}=t_{\text {ads/des }}+t_{\text {switching }}
$$

The amount of heat received by oil per cycle time from exhaust gas and delivered to water is estimated by

$$
Q_{\text {oil }}=\frac{\int_{0}^{t_{c y c l e}} \dot{m}_{\text {oil }} C_{p, \text { oil }}\left(T_{\text {oil,in }}-T_{\text {oil }, \text { out }}\right) d t}{t_{c y c l e}}
$$

The cycle average heat added to regenerate the vapor at the regeneration bed is

$$
Q_{\text {oil }}=\frac{\int_{0}^{t_{c y c l e}} \dot{m}_{\text {oil }} C_{p, \text { oil }}\left(T_{\text {oil,in }}-T_{\text {oil,out }}\right) d t}{t_{\text {cycle }}}
$$

The cycle average heat removed from the car cabin to the chilled water is given by

$$
Q_{\text {Load }}=\frac{\int_{0}^{t_{c y c l e}} \dot{m}_{c h w} C_{p, c h w}\left(T_{c h w, i n}-T_{c h w, o u t}\right) d t}{t_{c y c l e}}
$$

Finally the performance of the ADC is calculated in terms of $\mathrm{COP}$ and $\mathrm{SCP}$ and are given by

$$
\begin{aligned}
& C O P=\frac{Q_{\text {Load }}}{Q_{\text {add }}} \\
& S C P=\frac{Q_{\text {Load }}}{2 * M_{\text {ads }}} \text { (for two bed systems) }
\end{aligned}
$$

\section{Results and discussion}

In order to meet the cooling requirement of a private car cabin, a $3 \mathrm{~kW}$ adsorption cooling system has been designed. On the basis of cooling capacity, an exhaust gas heat recovery system has been designed in such a way that $7.5 \mathrm{~kW}$ heat can be transferred from the exhaust gas to the oil and finally the same amount of heat can be delivered to water to regenerate the adsorbate vapor from the desorption bed. Design parameters of all the heat transfer components and the operating parameters of adsorption cooling system used for simulation are listed in Table 3. The thermodynamic behaviors of the heat recovery system and performances of the ADC in terms of COP and SCP stemmed from the proposed model are discussed in this section.

Fig. 2 presents the exhaust gas outlet temperature from the economizer with time. Due to the very high heat transfer from exhaust gas to oil initially because of

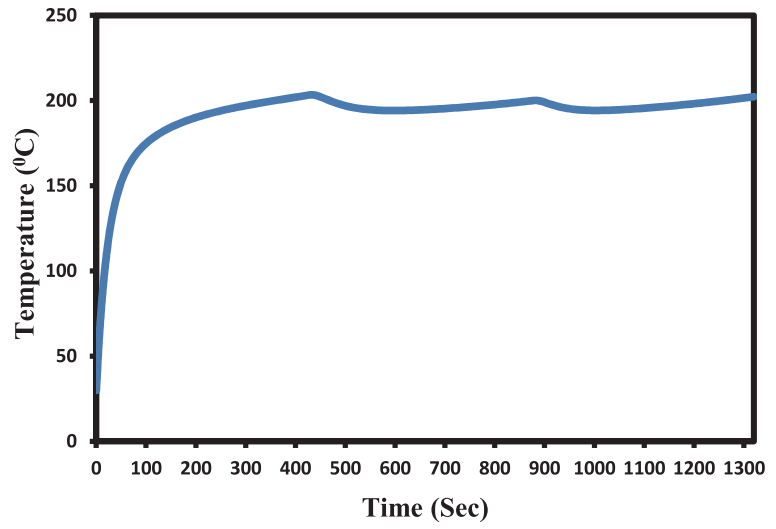

Fig. 2. Exhaust gas outlet temperature from economizer.

higher temperature difference between them, exhaust gas outlet temperature is low at the beginning. But with the increase in time, receiving heat from exhaust gas oil temperature increases. As a result heat transfer from exhaust gas decreases and exhaust gas outlet temperature increases. It reaches the ultimate temperature $200^{\circ} \mathrm{C}$ after the normal desorption time $420 \mathrm{sec}$.

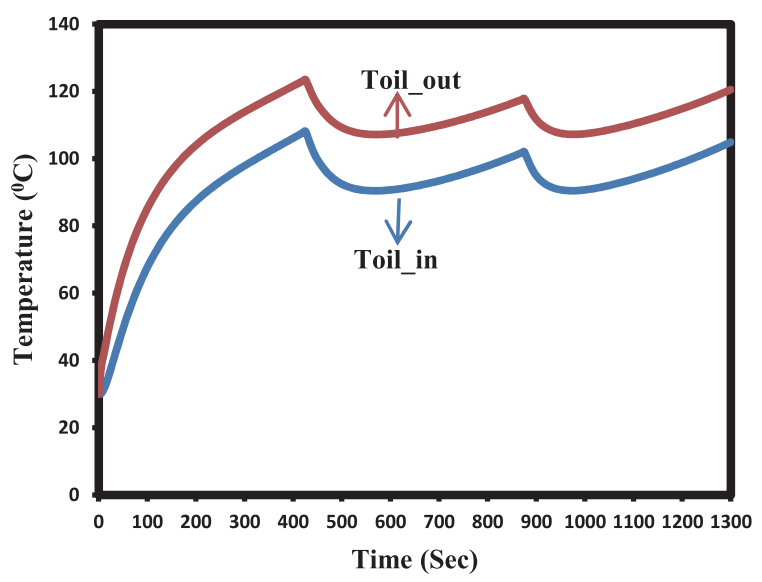

Fig. 3. Inlet and outlet temperature of oil from economizer.

During the switching period hot water from generator flows through the cold adsorption bed instead of hot desorption bed, so the heat transfer from exhaust gas to oil increases and exhaust gas outlet temperature decreases again. Fig. 3 shows the temporal evolution of heat transfer oil. It can be observed that the oil inlet and outlet temperatures of the economizer increases with time from $30^{\circ} \mathrm{C}$ as it receives heat from the exhaust gas and is circulated through the economizer and generator where it delivers the heat to water. At the beginning of switching period, both the oil inlet and outlet temperature drops up to $107^{\circ} \mathrm{C}$ and $91^{\circ} \mathrm{C}$ respectively due to the transfer of cooling water to the economizer. 
Table 3 Parameter values used in simulation.

\begin{tabular}{|c|c|c|c|}
\hline$M_{a d s}$ & $6 \mathrm{~kg}$ & $\dot{m}_{c h w-e v p}$ & $0.14 \mathrm{~kg} / \mathrm{s}$ \\
\hline$C_{p, a d s}$ & $0.921 \mathrm{KJ} / \mathrm{kg}[25]$ & $U_{\text {evp }}$ & $4.835122 \mathrm{KW} / \mathrm{m}^{2}-\mathrm{K}[42]$ \\
\hline$M_{H X, b e d} C_{p, H X}$ & $10.456 \mathrm{Kg} \cdot(\mathrm{KJ} / \mathrm{kg}-\mathrm{K})$ & $A_{\text {evp }}$ & $0.15548 \mathrm{~m}^{2} \quad$ [designed value] \\
\hline$U_{\text {bed }}$ & $0.250 \mathrm{KW} / \mathrm{m}^{2}-\mathrm{K} \quad[25]$ & $M_{\text {cond }}^{\text {ref }}$ & $5 \mathrm{~kg}$ \\
\hline$A_{\text {bed }}$ & $5 \mathrm{~m}^{2}$ & $M_{e v p}^{r e f}$ & $25 \mathrm{~kg}$ \\
\hline$\dot{m}_{c w-b e d}$ & $0.3 \mathrm{~kg} / \mathrm{s}$ & $T_{c h w, i n}$ & $12^{\circ} \mathrm{C}$ \\
\hline$\dot{m}_{h w-b e d}$ & $0.3 \mathrm{~kg} / \mathrm{s}$ & $T_{c w-b e d-i n}$ & $30^{\circ} \mathrm{C}$ \\
\hline$M_{H X, \text { cond }} C_{p, H X}$ & $0.215434 \mathrm{Kg} *(\mathrm{KJ} / \mathrm{kg}-\mathrm{K})$ & $T_{c w-c o n d-i n}$ & $30^{\circ} \mathrm{C}$ \\
\hline$\dot{m}_{c w-c o n d}$ & $0.18 \mathrm{~kg} / \mathrm{s}$ & t_cycle & $420 \mathrm{Sec}$ \\
\hline$U_{\text {cond }}$ & $7.641651 \mathrm{KW} / \mathrm{m}^{2}-\mathrm{K}[42]$ & $\mathrm{t}$ ssw & $30 \mathrm{Sec}$ \\
\hline$A_{\text {cond }}$ & $0.119907 \mathrm{~m}^{2} \quad$ [designed value] & $\dot{m}_{o i l}$ & 0.11 \\
\hline$M_{H X, e v p} C_{p, H X}$ & $0.279306 \mathrm{~kg} *(\mathrm{KJ} / \mathrm{kg}-\mathrm{K})$ & $C_{p, o i l}$ & $2.67 \mathrm{KJ} / \mathrm{kg}-\mathrm{K}[38]$ \\
\hline$\dot{m}_{E q}$ & $0.03 \mathrm{~kg} / \mathrm{s}$ & $\dot{m}_{\text {water }}$ & $0.3 \mathrm{~kg} / \mathrm{s}$ \\
\hline$C_{p, E g}$ & $1.15 \mathrm{~kg} / \mathrm{s}$ & $M_{H X, E g} C_{p, H X}$ & $1.76079 \mathrm{~kg} *(\mathrm{KJ} / \mathrm{kg}-\mathrm{K})$ \\
\hline$M_{H X, O i l} C_{p, H X}$ & $0.11031 \mathrm{~kg} *(\mathrm{KJ} / \mathrm{kg}-\mathrm{K})$ & $U_{H X, E g}$ & $0.1049215 \mathrm{~kg} *(\mathrm{KJ} / \mathrm{kg}-\mathrm{K})$ \\
\hline$U_{H X, O i l}$ & $7.6758831 \mathrm{~kg} *(\mathrm{KJ} / \mathrm{kg}-\mathrm{K})[38]$ & $A_{H X, E g}$ & $0.492 \mathrm{~m}^{2}$ \\
\hline$A_{H X, O i l}$ & $0.030748 \mathrm{~m}^{2} \quad$ [designed value] & & \\
\hline
\end{tabular}

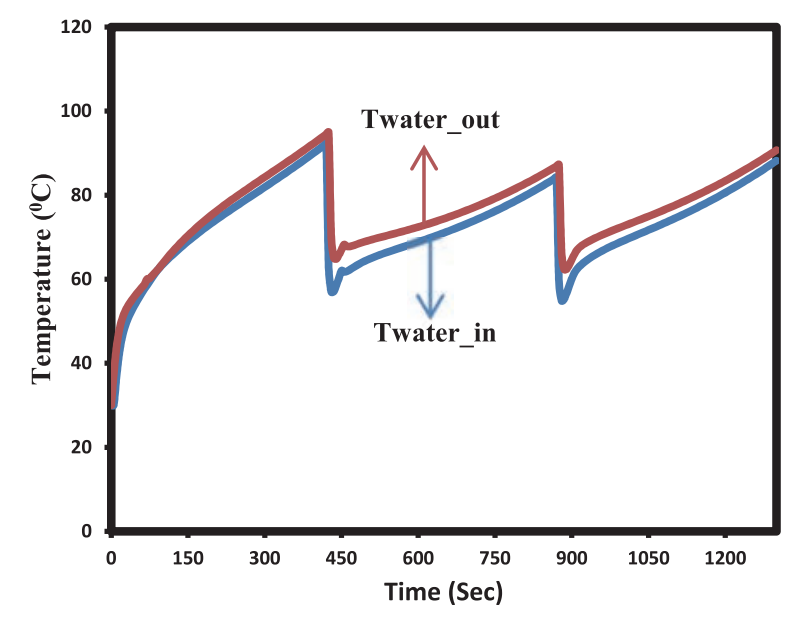

Fig. 4 Inlet and outlet temperature of water from generator.

Fig. 4 shows the transient thermal behavior of hot water. Due to heat transfer from the heated oil, the water outlet temperature increases at the beginning of the adsorption cooling cycle. Hot water ranging from 55 to $100{ }^{\circ} \mathrm{C}$ is then circulated to the desorption bed where it releases heat energy for the desorption of water vapor. Once the switching period starts, the hot water passes through the adsorption bed (initial temperature of $31^{\circ} \mathrm{C}$ ). Due to $60^{\circ} \mathrm{C}$ $(=90-30)$ temperature difference, the water outlet temperature suddenly falls down and reaches $64^{\circ} \mathrm{C}$ from $93^{\circ} \mathrm{C}$ when switching period is over. As time progresses, the adsorption bed receives heat from the hot water and its temperature increases. As a result heat transfer from oil is

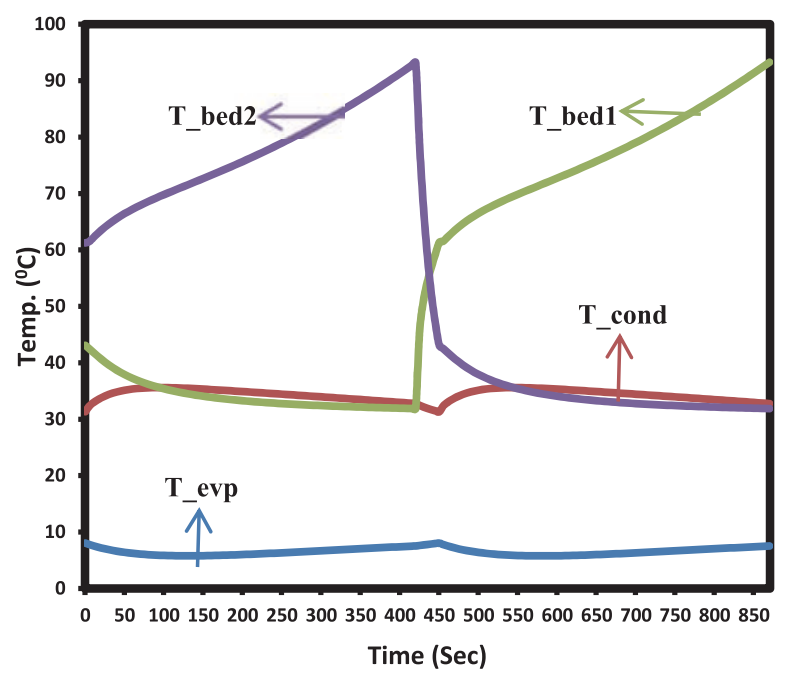

Fig. 5. Transient temperature profiles of the major components of ADC.

reduced and the water temperature increases again until the next switching period starts.

Fig. 5 shows the temporal profiles of the major components of ADC for the parameters listed in Table 3. It can be observed from the Figure that the evaporator temperature varies from $7^{\circ} \mathrm{C}$ to $10^{\circ} \mathrm{C}$ during adsorption period. It can also be noticed that the evaporator temperature drops initially from $8^{\circ} \mathrm{C}$ to the lowest evaporator temperature $5^{\circ} \mathrm{C}$ and then increases up to $8^{\circ} \mathrm{C}$. This is because of the higher adsorption rate at the 
beginning of the adsorption cycle. During the switching period, as there is no adsorption and the chilled water continues to absorb heat energy from the car cabin, the evaporator temperature increases further from $7^{\circ} \mathrm{C}$ to $8^{\circ} \mathrm{C}$. The condenser temperature shows the opposite trend of evaporator temperature. During operation periods, the condenser temperature increases from $31^{\circ} \mathrm{C}$ to $36^{\circ} \mathrm{C}$ initially due to the higher desorption rate at the beginning of desorption and then falls down to $32^{\circ} \mathrm{C}$. The condenser temperature decreases further to $31^{\circ} \mathrm{C}$ during the switching period because there is no desorption. On the other hand, the adsorption bed temperature shows a decreasing trend from $55^{\circ} \mathrm{C}$ to $31^{\circ} \mathrm{C}$ during adsorption period as $30^{\circ} \mathrm{C}$ cooling water flows through the reactor. During the switching period, the hot water passes through it and temperature increases from $31^{\circ} \mathrm{C}$ to $59^{\circ} \mathrm{C}$. On the other hand, the desorption bed temperature increases from $55^{\circ} \mathrm{C}$ to $91^{\circ} \mathrm{C}$. It should be noted here that previously, most of the researchers assumed around $80^{\circ} \mathrm{C}$ as constant hot water temperature due to the nature of hydrophobicity for the water vapor pressures of $6 \mathrm{kPa}$ at $80^{\circ} \mathrm{C}$ [29-33 ]. This study found that the hot water outlet temperature from generator is not constant but it increases from $30^{\circ} \mathrm{C}$ to $93^{\circ} \mathrm{C}$. So initially the rate of increase of desorption bed temperature is lower than the previously reported values. As a result, it takes the whole desorption period to reach the ultimate bed temperature $91{ }^{\circ} \mathrm{C}$ linearly. During the switching period the cooling water of $30^{\circ} \mathrm{C}$ flows through the bed so that its temperature decreases up to $43^{\circ} \mathrm{C}$.

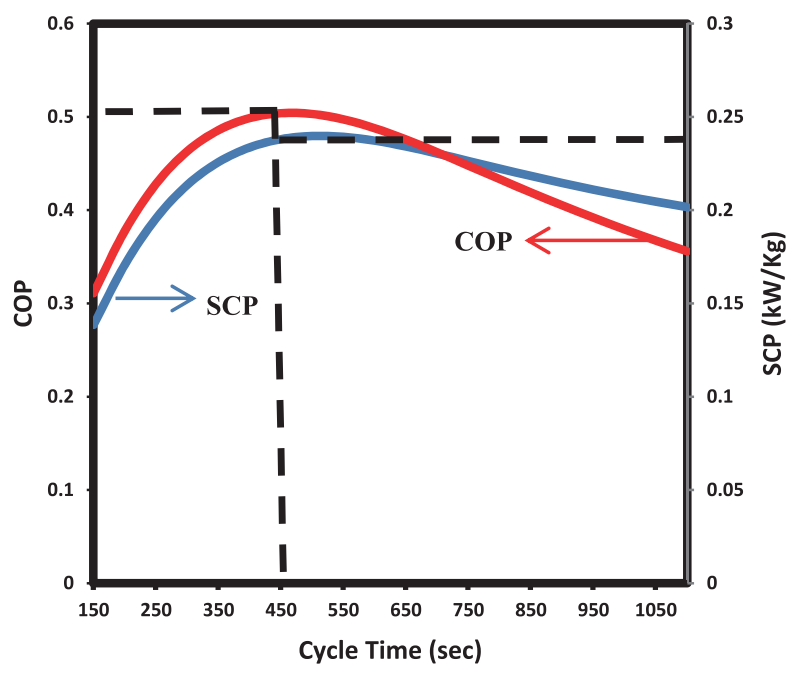

Fig. 6 Effect of cycle time on COP and SCP.

Fig. 6 shows the effects of cycle time on the performances of adsorption cooling system. It shows that both the COP and SCP increase with the cycle time when cycle time is shorter than $450 \mathrm{~s}$. Because adsorption and desorption bed reaches the saturation at $450 \mathrm{~s}$. The COP and the SCP reach their peak values at 0.5 and $0.24 \mathrm{~kW} / \mathrm{kg}$, respectively. The rate of adsorption and desorption decreases for the longer cycle time. So the cooling effect decreases but the heat of desorption increases. Hence both the COP and SCP drop at the longer cycle time.

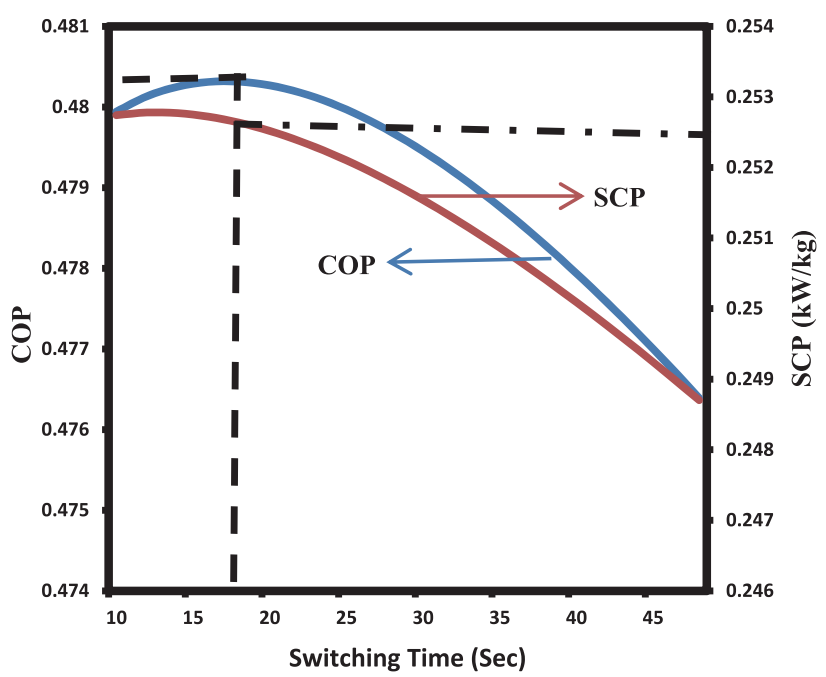

Fig. 7 Influence of switching time on ADC performance.

Fig. 7 depicts the consequences of switching time over adsorption cooling system performance. It shows that the switching time does not affect the system performance as much the cycle time does. It can be realized that both the COP and SCP are low for shorter switching time. The shorter switching time causes higher adsorption bed saturation pressure and lower desorption bed saturation pressure which leads to the insufficient adsorption and desorption effect.

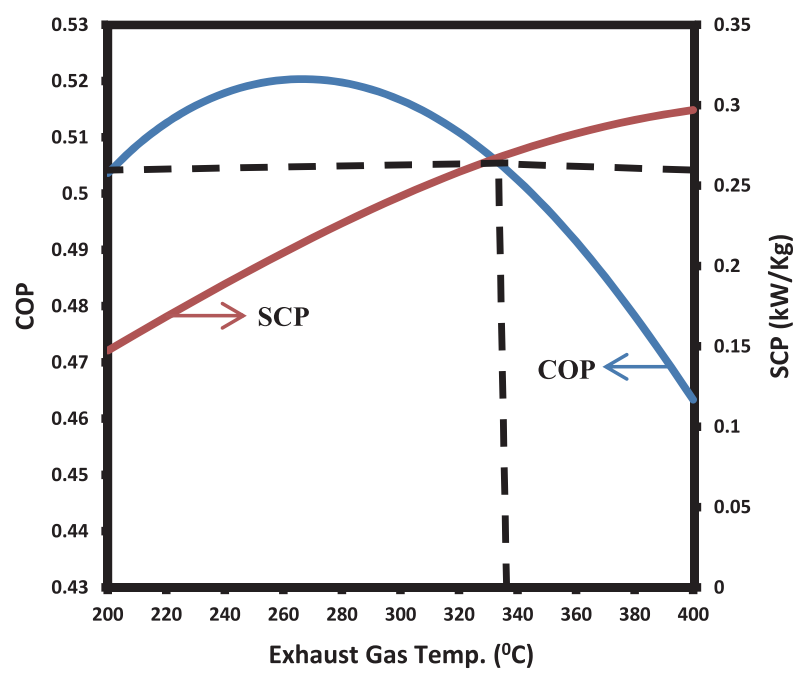

Fig. 8. Effect of exhaust gas temperature.

Fig. 8 describes the effect of Exhaust gas inlet temperature on COP and SCP of adsorption cooling system. It shows that COP is low for very high and very low exhaust gas temperature. Because the low exhaust gas inlet temperature causes insufficient desorption effect but on the other hand very high exhaust gas inlet temperature decreases the rate of desorption $(\mathrm{dw} / \mathrm{dt})$ as it reaches closer 
to the corresponding equilibrium uptake capacity. The maximum COP 0.52 is obtained at the exhaust gas inlet temperature of $270^{\circ} \mathrm{C}$. In contrast the SCP increases with the increase in exhaust gas inlet temperature.

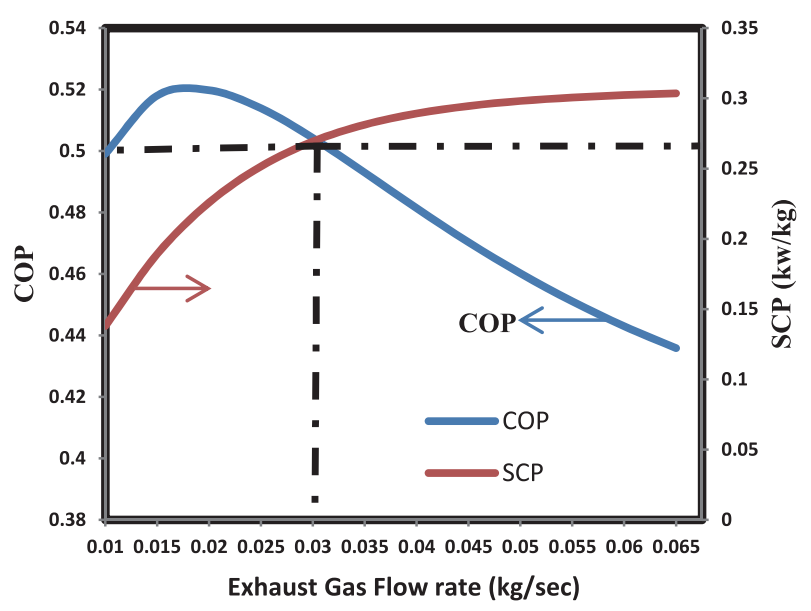

Fig. 9 Effect of exhaust gas flow rate.

Fig. 9 describes the effect of exhaust gas flow rate. It shows that the COP decreases for the very low exhaust gas flow rate because it cannot produce sufficient desorption effect. The COP reaches its maximum value $(\sim 0.52)$ when the exhaust gas flow rate is $0.02 \mathrm{~kg} / \mathrm{s}$. Further increase in exhaust gas flow rate does not increase the desorption effect significantly which causes a reduction in COP. The SCP increases with the increase in exhaust gas flow rate and remains almost constant after reaching its maximum value of 0.3 when the exhaust gas flow rate is $0.055 \mathrm{~kg} / \mathrm{s}$ as at this flow rate almost all the vapor regenerates from the bed. Hence an increase in the flow rate does not improve the desorption rate of the system. As a result the the SCP remains constant.

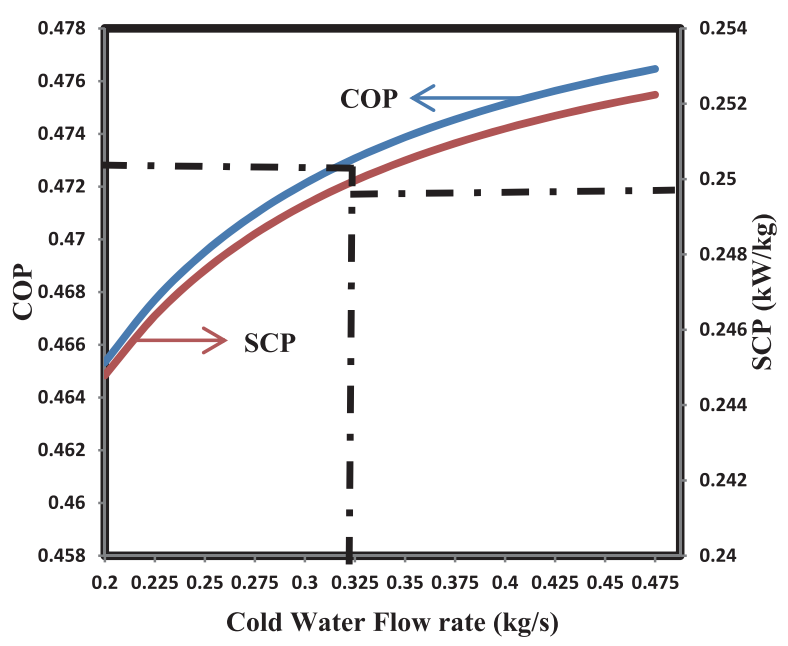

Fig. 10 Effect of cooling water flow rate.

The optimized values of the COP and the SCP can be noted from Figure 9 are 0.5 and $0.26 \mathrm{~kW} / \mathrm{kg}$ when the exhaust gas flow rate is $0.03 \mathrm{~kg} / \mathrm{s}$.
Fig. 10 explains the effect of the cooling water flow rate. It shows that the increase in the cooling water flow rate increases both the COP and the SCP. Since the higher cooling water flow rate reduces the adsorption bed saturation pressure and desorption bed vapor pressure, the adsorption and desorption effect enhances. As a result the COP and SCP of ADC both increases with the increase in cooling water flow rate. At higher cooling water flow rates, the cooling energy requirement increases but both the COP and the SCP do not improve significantly, the optimum values of the COP and SCP are 0.47 and 0.25 $\mathrm{kW} / \mathrm{kg}$ when cooling water flow rate is $0.32 \mathrm{~kg} / \mathrm{s}$.

\section{Conclusions}

The present study models mathematically and simulates an adsorption cooling system that symbiotically combines (i) the exhaust heat generated from the automotive engine through an economizer and generator, and (ii) the recooling of adsorption beds and condenser by air cooled radiator. Dynamic responses of the heat recovery system have been investigated by simulating the presented mathematical modelling of ADC. In addition to this an adsorption cooling system has been designed for average private car cabin cooling load of $3 \mathrm{~kW}$. Finally the models of the heat recovery system and the adsorption cooling system have been combined to investigate the optimized performances of the overall system in terms of COP and SCP for different operating parameters. The main findings of this study are as follows:

- Heat obtained from the exhaust gas of a six cylinder $3000 \mathrm{cc}$ petrol engine based private car can produce enough cooling for its cabin without increasing fuel consumption.

- Hot water inlet temperature to the desorption bed is not constant rather it varies in a range depending on the design of heat exchangers of the heat recovery system.

- Desorption bed temperature during desorption period varies linearly.

- Optimized COP and SCP of a $3 \mathrm{~kW}$ adsorption cooling system using silica gel + water as adsorbent + adsorbate pair are 0.47 and 0.25 $\mathrm{kW} / \mathrm{kg}$ respectively. 
EVERGREEN Joint Journal of Novel Carbon Resource Sciences \& Green Asia Strategy, Volume 02, Issue 01, March 2015

\begin{tabular}{|c|l|l|l|}
\hline \multicolumn{2}{|l|}{ Nomenclature } & $h$ & Enthalpy $(\mathrm{Kj} / \mathrm{Kg})$ \\
\hline$A$ & Area $\left(\mathrm{m}^{2}\right)$ & $t$ & Time $(\mathrm{s})$ \\
\hline$C_{p}$ & Specific heat $(\mathrm{Kj} / \mathrm{KgK})$ & $U$ & Overall heat transfer coefficient $\left(\mathrm{kW} / \mathrm{m}^{2}-\mathrm{K}\right)$ \\
\hline$D_{s o}$ & Kinetic Constant $\left(\mathrm{m}^{2} / \mathrm{s}\right)$ & $C O P$ & Coefficient of Performance \\
\hline$E_{a}$ & Activation Energy $(\mathrm{Kj} / \mathrm{Kg})$ & $S C P$ & Specific Cooling Power \\
\hline$w^{*}$ & Equilibrium uptake $(\mathrm{Kg} / \mathrm{Kg}$ of Adsorbent $)$ & Subscripts \\
\hline$w_{m}$ & Limiting Uptake $(\mathrm{Kg} / \mathrm{Kg}$ of Adsorbent $)$ & $a d s$ & Adsorption \\
\hline$w$ & Instantaneous Uptake $(\mathrm{Kg} / \mathrm{Kg}$ of Adsorbent $)$ & des & Desorption \\
\hline$K_{0}$ & Pre-exponential constant & $c w$ & Cooling Water \\
\hline$Q$ & Heat & $h w$ & Hot Water \\
\hline$R$ & Ideal Gas Constant $(\mathrm{Kj} / \mathrm{Kg}-\mathrm{mol})$ & $H X$ & Heat Exchanger \\
\hline$T$ & Temperature $\left({ }^{\circ} \mathrm{C}\right)$ & $c h w$ & Chilled Water \\
\hline$P$ & Pressure $(\mathrm{KPa})$ & $c o n d$ & Condenser \\
\hline$R_{p}$ & Particle Radius $(\mathrm{mm})$ & $e v p$ & Evaporator \\
\hline$M$ & Mass $(\mathrm{Kg})$ & $r e f$ & Refrigerant \\
\hline$\dot{m}$ & Mass flow rate $(\mathrm{Kg} / \mathrm{s})$ & Eg & Exhaust Gas \\
\hline & &
\end{tabular}

\section{References}

1) S.C. Davis, S.W. Diegel, R. G. Boundy, Transportation Energy Data Book, Edition 31, Office of Energy Efficiency and Renewable Energy, U.S. Department of Energy (2012)

2) C. Christy and R. Toossi, Adsorption AirConditioning for Containerships and Vehicles, METRANS Transportantion Centre Report 00-7, (2004)

3) G. Leduc, I. Mongelli, A. Uihlein, A. Nemry, "How can our cars become less polluting? An assessment of the environmental improvement potential of cars", Materials, 17, 409 - 419 (2010).

4) M. Winther, "Petrol passenger car emissions calculated with different emission models", The Science of the Total Environment, 224, 149 - 160 (1998).

5) J.Q. Hansen, M. Winther, S.C. Sorenson, "The influence of driving patterns on petrol passenger car emissions", The Science of the Total Environment, 169, 129-139 (1995).

6) M. Baglione, M. Duty, G. Pannone, "Vehicle system energy analysis methodology and tool for determining vehicle subsystem energy supply and demand", SAE technical paper: 2007-01-0398, SAE World Congress, Detroit, Michigan, April (2007).

7) A. Bandivadekar, K. Bodek, L. Cheah, C. Evans, T. Groode, J. Heywood, E. Kasseris, M. Kromer, M. Weiss, "On The Road in 2035: Reducing Transportation's Petroleum Consumption and GHG Emissions", MIT Laboratory for Energy and the Environment, Report No. LFEE 2008-05 RP, Cambridge, Massachusetts (2008).
8) A. Chakraborty, B.B. Saha, S. Koyama, T. Kashiwagi, A. Akisawa, K.C. Ng, H.T. Chua, "Waste heat driven dual-mode, multi-stage, multi-bed regenerative adsorption system", International Journal of Refrigeration, 26, 749-757 (2013).

9) K. Thu, B.B. Saha, A. Chakraborty, "Study on an advanced adsorption desalination cycle with evaporator-condenser heat recovery circuit", International Journal of Heat and Mass Transfer, 54, 43 - 51(2011).

10) I. I. Sharkawy, H. AbdelMeguid, B.B. Saha, "Towards an optimal performance of adsorption chillers: Reallocation of adsorption/desorption cycle times", International Journal of Heat and Mass Transfer, 63, 171-182 (2013).

11) K.C. Chan, Y.H. Christopher, "Performance predictions for a new zeolite $13 \mathrm{X} / \mathrm{CaCl} 2$ composite adsorbent for adsorption cooling systems", International Journal of Heat and Mass Transfer, 55, 3214-3224 (2012).

12) X. Wang, H.T. Chua, "Two bed Silica-gel water adsorption chillers: An effectual lumped parameter model", International Journal of Refrigeration, 30, 1417 - 1426 (2007).

13) B.B. Saha, A. Chakraborty, Y.I. Aristov, "A new generation cooling device employing $\mathrm{CaCl} 2$ - inSilica gel-water system", International Journal of Heat and Mass Transfer, 52, 516-524 (2009).

14) A. Rezk, R. Al-Dadah, Mahmoud, A. Elsayed, "Characterisation of Metal Organic Framework for adsorption cooling", International Journal of Heat and Mass Transfer, 55, 7366-7374 (2012).

15) N. O. Omisanya, C. O. Folayan, S. Y. Aku, S. S. Adefila, "Performance of a zeolite - water adsorption 
refrigerator", Advances in Applied Science Research, 3, 3737-3745 (2012).

16) H. T. Chua, A. Chakraborty, $X$. Wang, "An Adsorption Chillier Driven by Thermoelectricity", Proc. International Refrigeration and Air Conditioning Conference, Paper 677, 2004.

17) D.C. Wang, Z.Z. Xia, J.Y. Wu, "Design and performance prediction of a novel zeolite-water adsorption air conditioner", Energy Conversion and Management, 47, 590-610 (2006).

18) H.T. Chua, K.C. Ng, A. Maleka, T. Kashiwagi, A. Akisawa, B.B. Saha, "Modelling the performance of two-bed, sillica gel-water adsorption chillers", International Journal of Refrigeration, 22, 194-204 (1999).

19) D.C. Wang, Z.Z. Xia, J.Y. Wu, R.Z. Wang, H. Zhai, W.D. Dou, "Study of a novel silica gel-water adsorption chiller. Part I. Design and performance prediction", International Journal of Refrigeration, 28, 1073-1083 (2005).

20) A. Al-Ansari, H. Ettouney, H. El-Dessouky, "Waterzeolite adsorption heat pump combined with single effect evaporation desalination process", Renewable Energy, 24, 91-111 (2001).

21) T. Miyazakia, A. Akisawa, B.B. Saha, I.I. ElSharkawy, A. Chakraborty, "A new cycle time allocation for enhancing the performance of two-bed adsorption chillers", International Journal of Refrigeration, 32, 846 - 853 (2009).

22) B.B. Saha, I.I. El-Sharkawya, A. Chakraborty, S. Koyama, N.D. Banker, P. Dutta, M. Prasad, K. Srinivasan, "Evaluation of minimum desorption temperatures of thermal compressors in adsorption refrigeration cycles", International Journal of Refrigeration, 29, 1175-1181 (2006).

23) K. Habib, B.B. Saha, A. Chakraborty, S. Koyama, K. Srinivasan, "Performance evaluation of combined adsorption refrigeration cycles", International Journal of Refrigeration, 34, 129 -137 (2011).

24) B.B. Saha, A. Chakraborty, S. Koyama, K.C. Ng, M. A. Sai, "Performance modelling of an electroadsorption chiller", Philosophical Magazine, 86, 3613-3632 (2006).

25) K.C. Ng, K. Thu, B.B. Saha, A. Chakraborty, "Study on a waste heat-driven adsorption cooling cum desalination cycle", International Journal of Refrigeration, 35, 685 - 693 (2012).

26) K. Habib, B.B. Saha, A. Chakraborty, S.T. Oh, S. Koyama, "Study on solar driven combined adsorption refrigeration cycles in tropical climate", Applied Thermal Engineering, 50, 1582-1589 (2013).

27) J. M. Gordon, K.C. Ng, H.T. Chua, A. Chakraborty, "The electro-adsorption chiller: a miniaturized cooling cycle with applications to micro-electronics", International Journal of Refrigeration, 25, 10251033 (2002).
28) X. Wang, H.T. Chua, K.C. Ng, "Simulation of the Silica Gel-Water Adsorption Chillers", International Refrigeration and Air Conditioning Conference, Paper 663 (2004).

29) Y.Z. Lu, R.Z. Wang, S. Jianzhou, M. Zhang, Y.X. Xu, J.Y. Wu, "Performance of a Diesel Locomotive Waste-Heat-Powered Adsorption Air Conditioning System", Adsorption, 10, 57-68 (2004).

30) M. A. Lambert, B. J. Jones, "Automotive adsorption air conditioner powered by exhaust heat. Part 1: conceptual and embodiment design", Journal of Automobile Engineering, 220, 959-972 (2006).

31) M. A. Lambert, B. J. Jones, "Automotive Adsorption Air Conditioner Powered by Exhaust Heat. Part 2: detailed design and analysis", Journal of Automobile Engineering, 220, 973-979 (2006).

32) Y. ZHONG, L.W. Kevin, T. Fang, “An Adsorption Air-Conditioning System to Reduce Engine Emissions and Fuel Consumption for Heavy-Duty Vehicles", International Refrigeration and Air Conditioning Conference, Paper 1100 (2010).

33) M. Verde, L. Cortes, J.M. Corberan, A. Sapienza, S. Vasta, G. Restuccia, "Modelling of an adsorption system driven by engine waste heat for truck cabin A/C. Performance estimation for a standard driving cycle", Applied Thermal Engineering, 30, 1511-1522 (2010).

34) K.C. Ng, et.al., "Experimental investigation of the silica gel-water adsorption isotherm characteristics", Applied Thermal Engineering, 21, 1631-1642 (2001).

35) H.T. Chua, K. C. Ng, A. Chakraborty, N. M. Oo, M. A. Othman, "Adsorption Characteristics of Silica Gel + Water Systems", Journal of Chemical Engineering Data, 47, 1177-1181 (2002).

36) K. Thu, A. Chakraborty, B.B. Saha, K.C. Ng, "Thermo-physical properties of silica gel for adsorption desalination cycle", Applied Thermal Engineering, 50, 1596-1602 (2013).

37) M. Ehsan, M. Z., "Study of temperature profile in automotive exhaust system for retrofitting catalytic converters", Internal Conference on Mechanical Engineering, Dhaka, Bangladesh, (2005).

38) Shell Heat Transfer Oil S2, Retrieved June 24, 2014, http://www.epc.shell.com/Docs/GPCDOC_GTDS_S hell_Heat_Transfer_Oil_S2_(en)_TDS.pdf.

39) K.Y. Foo, B.H. Hameed, "Insight into the modelling of adsorption isotherm systems", Chemical Engineering Journal, 156, 2-10 (2010).

40) D.D. Do, Adsorption Analysis: Equilibria and Kinetics, Vol.2, Imperial College Press, London, 125130 (1998).

41) M. Suzuki, Adsorption Engineering, Kodanasha Ltd., Tokyo, 5-10 (1990).

42) J.P. Holman, Heat Transfer, 9th ed., McGraw-Hill Book (2002). 